\title{
UPAYA MENINGKATKAN \\ HASIL BELAJAR IPA DENGAN METODE DEMONSTRASI MASA PANDEMI COVID 19 PADA SISWA KELAS VI SDN 2 KELAYU JORONG SEMESTER I TAHUN 2021/2022
}

\author{
SUHARYATI \\ SDN 2 KELAYU JORONG \\ email: suharyati357@gmail.com
}

\begin{abstract}
ABSTRAK
Penelitian ini merupakan Penelitian Tindakan Kelas (PTK) yang dilaksanakan untuk meningkatkan hasil belajar IPA pada siswa kelas VI SDN 2 Kelayu Jorong tahun Pelajaran 2021/2022 dengan menggunakan metode demonstrasi. Subyek penelitian ini adalah siswa kelas VI SDN 2 Kelayu Jorong tahun 2021/2022 yang berjumlah 18 orang terdiri dari 9 orang laki-laki dan 9 orang perempuan. Proses pelaksanaan tindakan pembelajaran IPA dengan metode demonstrasi dalam penelitian ini dilaksanakan dalam 2 siklus. Berdasarkan data yang dikumpulkan dari penelitian tentang upaya meningkatkan hasil belajar IPA pada siswa kelas VI di SDN 2 Kelayu Jorong tahun 2021/2022 dengan menggunakan metode demonstrasi terlihat perubahan yang cukup signifikan dalam meningkatkan hasil belajar IPA pada siswa, di mana pada siklus kedua dari 18 orang sampel dalam penelitian ini 15 orang yang telah mencapai kriteria ketuntasan minimal individu dan itu berarti $83 \%$ dari keseluruhan siswa sampel telah mencapai keriteria ketuntasa individu yaitu di atas nilai 60, dan hal ini berarti telah mencapai kriteria ketuntasan individual.
\end{abstract}

Kata kunci: Metode Demonstrasi, Hasil Belajar, Magnet.

\begin{abstract}
This research is a Classroom Action Research (CAR) which was carried out to improve science learning outcomes in grade VI students of SDN 2 Kelayu Jorong in the 2021/2022 academic year by using the demonstration method. The subjects of this study were class VI students of SDN 2 Kelayu Jorong in 2021/2022, totaling 18 students consisting of 9 boys and 9 girls. The process of implementing science learning actions with the demonstration method in this study was carried out in 2 cycles. Based on data collected from research on efforts to improve science learning outcomes in grade VI students at SDN 2 Kelayu Jorong in 2021/2022 by using the demonstration method, there were significant changes in improving science learning outcomes for students, where in the second cycle, 18 students The sample in this study was 15 people who had achieved the minimum individual completeness criteria and that means $83 \%$ of the total sample students had achieved the individual completeness criteria, which was above the value of 60 , and this meant that they had achieved the individual completeness criteria.
\end{abstract}

Keywords: Demonstration Method, Learning Outcomes, Magnets. 


\section{PENDAHULUAN}

Ilmu Pengetahuan Alam (IPA) merupakan salah satu mata pelajaran yang wajib dipelajari di Sekolah Dasar. Siswa akan dapat mempelajari diri sendiri dan alam sekitar dengan belajar IPA. IPA juga merupakan salah satu disiplin ilmu yang berhubungan dengan cara mencari tahu tentang alam secara sistematis, sehingga IPA bukan hanya penguasaan kumpulan pengetahuan yang berupa fakta-fakta, konsep-konsep, atau prinsip-prinsip saja tetapi juga merupakan suatu proses penemuan dan memiliki sifat ilmiah.

Pembelajaran IPA adalah ilmu yang mempelajari peristiwa-peristiwa yang terjadi di alam dengan melakukan observasi, eksperimentasi, penyimpulan, penyusunan teori, agar siswa mempunyai pengetahuan, gagasan dan konsep yang terorganisasi tentang alam sekitar, yang diperoleh dari pengalaman melalui serangkaian proses ilmiah anatara lain penyelidikan, penyusunan dan penyajian gagasan-gagasan.

Pelajaran IPA ditingkat Sekolah Dasar merupakan mata pelajaran yang mencakup materi cukup luas. Guru diharuskan menyelesaikan target ketuntasan belajar siswa,sehingga perlu perencanaan dan pelaksanaan pembelajaran dengan menggunakan metode, media atau alat peraga dan strategi belajar yang tepat. Guru harus mampu menciptakan suasana pembelajaran yang menyenangkan selain dengan penggunaan metode dan strategi yang tepat,guru juga harus mampu memahami karakteristik siswa dan memberikan rangsangan kepada siswa agar bersemangat dalam mengikuti proses pembelajaran IPA di Sekolah Dasar. Ilmu Pengetahuan Alamuntuk siswa SD, ide-ide dan konsep-konsep harus disederhanakan sesuai dengan peristiwa-peristiwa yang betul-betul terjadi atau sudah pernah dialami. Siswa mendapatkan pengetahuan melalui praktek, meneliti secara langsung, dan bereksperimen terhadap objek-objek yang akan dipelajari,sehingga pembelajaranakan lebihbermanfaat dan efektif.

Pada umumnya metode yang digunakan guru dalam menyampaikan pelajaran adalah dengan metode ekspositori, yaitu dengan memaparkan informasi yang dianggap penting untuk siswa di awal pelajaran, memberikan definisi dan rumus, menjelaskan contoh soal dan cara pengerjaannya, memberikan soal-soal latihan untuk dikerjakan siswa dan kemudian memeriksa pekerjaan siswa di akhir pelajaran. Beberapa guru merasa cocok dengan metode tersebut, namun jika guru mengajar dengan metode yang sama pada setiap pertemuan maka tidak jarang akan ditemui siswa yang bosan untuk mempelajari materi ini, terjadi penurunan aktivitas belajar yang mengakibatkan menurunnya prestasi belajar IPA siswa.

Hasil pengamatan awal yang dilakukan peneliti diperoleh hasil bahwa pembelajaran IPA di kelas VI SD Negeri 2 Kelayu Jorong masih belum maksimal. Adapun proses pembelajaran IPA masih memerlukan pembelajaran yang tepat maksimal, terutama metode yang dapat membuat siswa berperan lebih aktif. Saat pembelajaran IPA. Sebanarnya guru sudah menggunakan berbagai metode mengajar yang menarik dan membuat siswa aktif, tapi belum malksimal sehingga nilai anak masih rendah, salah satunya pada pelajaran IPA Dilihat dari metode yang digunakan guru, siswa lebih banyak mendengarkan apa yang disampaikan guru. Kesempatan siswa berinteraksi dengan benda-benda kongkrit masih kurang. Sementara untuk anak usia SD masih dibutuhkan suatu yang nyata dalam membangun pengetahuan konseptualnya.

Untuk pelajaran IPA nilai rata-rata yang diperoleh siswa kelas VI pada materi kemagnetan sebelum dilakukannya penelitian dari 18 orang siswa adalah 52,77 dan persentase jumlah siswa yang mencapai standar ketuntasan belajar sebesar $44,44 \%$. Nilai ini masih jauh dari persentase jumlah siswa yang mencapai standar ketuntasan belajar mengajar (SKBM) yang ditetapkan di SDN 2 Kelayu Jorong yaitu sebesar $60 \%$.

Jika situasi pembelajaran tersebut dibiarkan dan tidak segera diatasi oleh guru maka akan berdampak negatif terhadap prestasi belajar IPA secara keseluruhan. Salah satu upaya guru untuk meningkatkan kembali aktivitas dan prestasi belajar IPA siswa adalah dengan melakukan perbaikan metode pembelajaran yang disesuaikan dengan komponen pembelajaran lainnya. 
Salah satu upaya mengatasi masalah adalah dengan menggunakan metode yang tepat. Pemberian pengetahuan kepada siswa merupakan proses pengajaran yang dilakukan oleh guru dengan menggunakan metodemetode tertentu

Salah satu metode pembelajaran yang yang digunakan peneliti dalam penelitian ini adalah metode demonstrasi. Metode demonstrasi adalah suatu model atau cara mengajar yang mengajak siswa untuk mempertunjukkan suatu pelajaran dengan cara terjun langsung melakukan suatu peragaan sampai selesai. Tujuannya adalah agar siswa tetap ingat pada pelajaran yang pernah diberikan gurunya sampai kapanpun.

\section{KAJIAN PUSTAKA}

\section{Hasil Belajar}

Hasil belajar tidak dapat dipisahkan dari perbuatan belajar, karena "belajar merupakan suatu proses sedangkan hasil belajar adalah hasil dari proses pembelajaran tersebut" (Slameto, 2003: 45)

Menurut Logan, dkk (dalam Sujana, 1998) belajar dapat diartikan "sebagai perubahan tingkah laku yang relatif menetap sebagai hasil pengalaman dan latihan

Sudjana (1998) berpendapat bahwa: "Belajar merupakan proses perubahan dari belum mampu menjadi sudah mampu dan terjadi dalam jangka waktu tertentu.

Jadi belajar adalah suatu proses usaha yang dilakukan siswa untuk memperoleh suatu perubahan tingkah laku yang baru secara keseluruhan, secara sengaja, disadari dan perubahan tersebut relatif menetap serta membawa pengaruh dan manfaat yang positif bagi siswa dalam berinteraksi dengan lingkungannya.

Menurut Chaplin, pengertian hasil belajar atau hasil belajar adalah : "Hasil belajar merupakan suatu tingkatan khusus yang diperoleh sebagai hasil dari kecakapan kepandaian, keahlian dan kemampuan di dalam karya akademik yang dinilai oleh guru atau melalui tes prestasi" (1992: 159). Pendapat Chaplin di atas mengandung pengertian bahwa prestasi itu hakikatnya berupa perubahan perilaku pada individu di sekolah, perubahan itu terjadi setelah individu yang bersangkutan mengalami proses belajar mengajar tertentu. Hasil belajar adalah kemampuan yang dimiliki siswa setelah ia ingin menerima pengalaman belajar atau yang optimal yang dapat dicapai dari kegiatan belajar di sekolah untuk pelajaran.

Jadi hasil belajar merupakan suatu nilai yang menunjukkan hasil belajar dari aktifitas yang berlangsung dalam interaksi aktif sebagai perubahan dalam pengetahuan, pemahaman keterampilan dan nilai sikap menurut kemampuan anak dalam perubahan baru. Dalam proses belajar mengajar anak didik merupakan masalah utama karena anak didiklah yang diharapkan dapat menyerap seluruh materi pelajaran yang diprogramkan didalam kurikulum.

Faktor-faktor yang mempengaruhi hasil belajar adalah:

a. Faktor intern yang meliputi: factor fisiologis yaitu yang berhubungan dengan kesehatan badan dan pancaindra. Dan factor psikologia yaitu yang berhubungan dengan intelegensi, sikap, dan motivasi.

b. Faktor ekstern yang meliputi factor keluarga, sekolah dan masyarakat.

\section{Metode Demonstrasi}

Menurut Winataputra (1997), metode demonstrasi merupakan metode mengajar yang menyajikan pelajaran dengan mempertunjukkan secara langsung obyek atau caranya melakukan sesuatu untuk mempertunjukkan suatu proses. Pendapat lain mengatakan bahwa metode demonstrasi adalah pertunjukan tentang proses terjadinya suatu peristiwa sampai pada penampilan tingkah laku yang dicontohkan agar dapat dipahami oleh peserta didik baik secara nyata maupun secara tiruan. Hal ini lebih cocok untuk gerakan yang sifatnya ke arah gerakan motorik disamping moral. Metode demonstrasi digunakan guru untuk mempertunjukkan gerakan dengan prosedur yang benar. (Muhibbinsyah 2004 : 85).
a. Tujuan 
Demonstrasi merupakan satu wahana untuk memberikan pengalaman belajar agar anak dapat menguasai kemampuan yang diharapkan dengan lebih baik. Tujuan metode demonstrasi adalah peniruan terhadap model yang dapat dilakukan dan memberikan pengalaman belajar melalui penglihatan dan pendengaran

b. Kelebihan Metode Demonstrasi

1. Membantu anak didik memahami dengan jelas jalannya suatu proses atau kerja suatu benda/peristiwa.

2. Memudahkan berbagai jenis penjelasan

3. Kesalahan-kesalahan yang terjadi dari hasil ceramah dapat diperbaiki melalui pengamatan dan contoh kongkret.

4. Perhatian anak dapat lebih terpusatkan.

5. Anak dapat ikut serta aktif apabila demonstrasi langsung dilanjutkan dengan eksperimen

6. Mengurangi kesalahankesalahan yang mungkin terjadi sekiranya anak hendak mencoba sendiri.

7. Beberapa persoalan yang belum dimengerti dapat ditanyakan lansung saat suatu proses ditunjukkan sehingga terjawab dengan jelas.

c. Kelemahan Metode Demonstrasi

1. Anak didik terkadang sukar melihat dengan jelas benda/peristiwa yang akan dipertunjukkan karena jumlah anak yang banyak dalam satu kelas atau alat yang terlalu kecil. Sehingga metode demonstrasi hanya efektif untuk sistem kelompok dan kurang efektif apabila menggunakan sistem klasikal.

2. Tidak semua benda/peristiwa dapat didemonstrasikan.

3. Sukar dimengerti apabila didemonstrasikan oleh guru yang kurang menguasai apa yang didemonstrasikan.
4. Apabila tidak dilanjutkan dengan eksperimen ada kemungkinan anak menjadi lupa, dan materi belajar tidak akan bermakna karena tidak menjadikan pengalaman belajar

d. Langkah-Langkah Metode

Demonstarsi

1. Merumuskan tujuan yang akan dicapai.

2. Mempersiapkan peralatan yang dibutuhkan.

3. Memeriksa appakah peralatan berfungsi atau tidak.

4. Menetapkan langkah pelaksanaan agar efisien.

5. Memperhitungkan dan menetapkan alokasi waktu.

6. Mengatur tata ruang yang memungkinkan seluruh siswa dapat memperhatikan pelaksanaan demonstrasi.

7. Menetapkan kegiatan yang dilaksanakan selama pelaksanaan.

Dalam penelitian ini, peneliti menggunakan penelitian yang relevan yaitu dari Erma Laini yang berjudul "Penerapan Metode Demonstrasi Untuk Meningkatkan Hasil Belajar IPA Siswa Kelas V SDN 015 SUMBER SARI TP. 2013/2014".

Berdasarkan hasil penelitian perbaikan pembelajaran Ilmu Pengetahuan Alam dengan menggunakan metode demonstrasi siswa lebih aktif, kreatif dan terjadi peningkatan hasil belajar, penulis dapat mengambil kesimpulan:

1. Penerapan metode demonstrasi ternyata dapat meningkatkan, baik dalam proses maupun hasil pencapaian hasil ketuntasan belajar siswa kelas V SD Negeri 015 Sumber Sari. Dapat dilihat dari hasil pelaksanaan tindakan kelas yang dilakukan 2 siklus, yaitu siklus I siswa yang tuntas sebanyak 25 0rang $(52,63 \%)$ dan siswa tidak tuntas 12 orang $(47,37 \%)$ pada siklus II siswa tuntas seluruhnya (100\%), sedangkan di SDN 2 Kelayu Jorong pada siklus I dari 18 siswa yang tuntas secara klasikal adalah 14 orang $(78 \%)$ 
dengan nilai rata-rata $69 \%$. Sedangkan pada siklus II jumlah siswa yang tuntas adalah 15 orang (83\%) dengan nilai rata-rata $84 \%$

2. Dengan menggunakan metode demonstrasi pembelajaran dapat meningkatkan penguasaan konsep, siswa aktif dan lebih percaya diri.

3. Dengan menggunakan metode demonstrasi pembelajaran IPA dapat memberikan dampak positif terhadap hasil belajar siswa.

\section{METODE PENELITIAN}

\section{Setting pnelitian}

a. Subyek Penelitian

Subyek penelitianadalah siswa kelas VI SD Negeri 2 Kelayu Jorong kecamatan Selong kabupaten Lombok Timur tahun pelajaran 2021/2022 yang berjumlah 18 siswa dan terdiri atas 9 siswa laki-laki dan 9 siswa perempuan dengan usia ratarata 12 tahun. b. Tempat dan Waktu Penelitian

Tempat penelitian ini adalah di SDN

2 Kelayu Jorong Kecamatan Selong, Kabupaten Lombok Timur tahun 2021/2022. Penelitian ini dilaksanakan selama kurang lebih tiga bulan, yaitu mulai Bulan Oktober sampai dengan Desember 2021

c. Jenis Penelitian

Jenis Penelitian yang diambil adalah Penelitian Tindakan Kelas (PTK), yaitu penelitian yang mengupayakan perbaikan proses pembelajaran yang hasilnya akan memberikan dampak bagi penigkatan aktivitas belajar siswa yang bermuara pada prestasi belajar.

\section{Prosedur Penelitian}

Dalam penelitian ini peneliti menggunakan desain dengan model Arikunto Suharsimi Arikunto

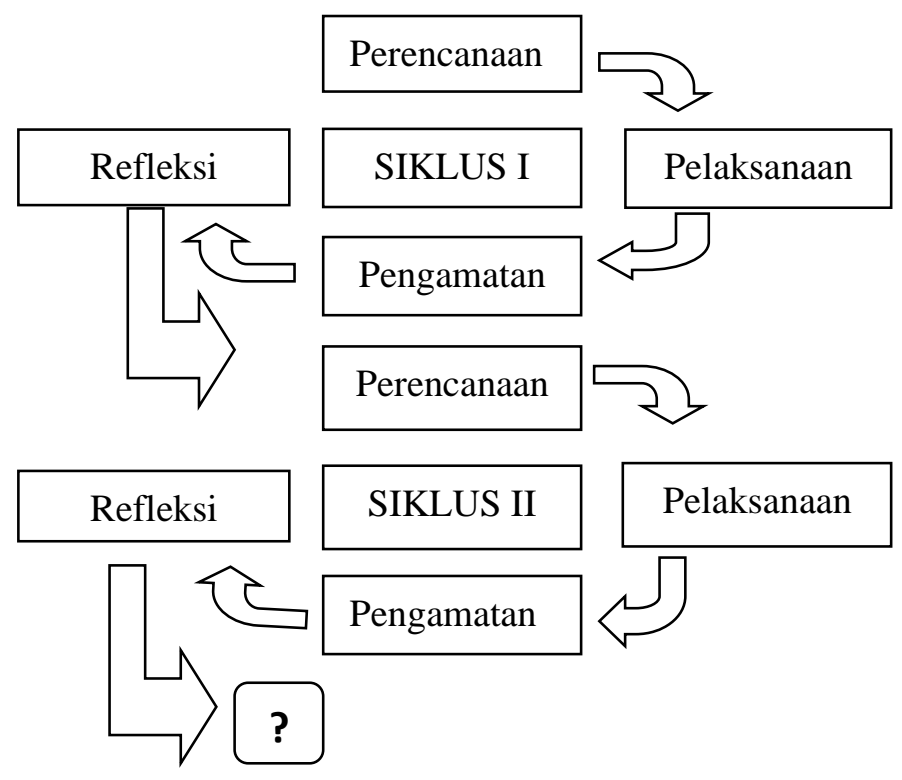

Penelitian ini dilaksanakan dengan menggunakan dua siklus, dengan setiap siklusnya dilaksanakan 2 kali pertemuan yang meliputi :
a. Perencanaan Tindakan
b. Pelaksanaan
c. Observasi dan Evaluasi
d. Refleksi

\section{Tehnik Pengumpulan Data}

a. Instrumen pelaksanaan pembelajaran

b. Instrumen pengumpulan data
1) Dokumentasi 
2) Observasi

3) Tes evaluasi pada setiap siklus

\section{Tehnik Analisa Data}
a. Data aktivitas siswa
b. Data tes hasil belajar

\section{HASIL PENELITIAN DAN PEMBAHASAN}

Data yang diperolah berupa data kuantitatif dari hasil evaluasi dan data kualitatif yang dikumpulkan dari hasil observasi. Data kuantitatif yang diperoleh dari hasil evaluasi akan memberikan jawaban mengenai keberhasilan atau tidaknya proses pembelajaran dengan menerapkan metode demonstrasi yang diukur dengan ketuntasan belajar secara klasikal. Data kualitatif diperoleh dari hasil observasi yang akan memberikan gambaran tentang aktivitas siswa maupun aktivitas guru yang dilakukan oleh observer pada setiap pertemuan pelaksanaan proses pembelajaran. Berikut ini akan disajikan data hasil penelitian pada setiap siklus yang telah direncanakan.

\section{Siklus I}

Pada tahap siklus I dilaksanakan membuat rencana pembelajaran dan

pelaksanaan kegiatan pembelajaran sesuai dengan rencana pelaksanaan pembelajaran yang telah dibuat. Untuk dapat menyesuaikan rencana pelaksanaan pembelajaran dalam penyampaian materi, termasuk didalamnya pembelajaran dengan menggunakan metode demonstrasi dilaksanakan dalam 3 kali pertemuan, dimana 2 kali pertemuan untuk penyampaian materi dan 1 kali pertemuan untuk evaluasi.

Hasil observasi diperoleh dari hasil pengamatan yang dilakukan oleh observer yang dilakukan oleh rekan guru peneliti dengan mengisi lembar observasi aktivitas guru dan aktivitas siswa untuk merekam jalannya proses pembelajaran. Dari hasil observasi dan pengamatan yang dilakukan, didapatkan bahwa proses pembelajaran belum sesuai dengan yang diharapkan karena masih terdapat kekurangan-kekurangan baik dari pihak guru sendiri maupun dari pihak siswa.

Berdasarkan hasil observasi terhadap aktivitas siswa setelah dianalisa diperoleh data sebagai berikut :

\begin{tabular}{|c|c|c|c|c|c|c|c|c|c|}
\hline \multirow{2}{*}{ Pertemuan } & \multicolumn{6}{|c|}{ Jumlah skor yang tampak } & \multirow{2}{*}{$\begin{array}{c}\Sigma \text { Skor } \\
\text { aktivitas }\end{array}$} & \multirow{2}{*}{$\begin{array}{l}\text { Rata-rata } \\
\text { Aktivitas }\end{array}$} & \multirow{2}{*}{ Kategori } \\
\hline & 1 & 2 & 3 & 4 & 5 & 6 & & & \\
\hline Pertama & 3,6 & 2,3 & 3,3 & 3,3 & 2,3 & 4,3 & 19,1 & 3,18 & $\begin{array}{l}\text { Cukup } \\
\text { Aktif }\end{array}$ \\
\hline Kedua & 3,6 & 3,0 & 3,6 & 3.0 & 3,6 & 4,3 & 21,3 & 3,5 & $\begin{array}{l}\text { Cukup } \\
\text { Aktif }\end{array}$ \\
\hline
\end{tabular}

Dari tabel di atas dapat dilihat bahwa aktivitas belajar siswa pada siklus I pertemuan 1 adalah 3,18 dengan kategori cukup aktif dan pertemuan 2 adalah 3,5 kategori cukup aktif. Sedangkan data hasil belajar yang diperoleh adalah:

\begin{tabular}{|c|l|l|l|l|l|}
\hline No. & \multicolumn{1}{|c|}{ Nama Siswa } & L/P & Skor & Nilai & $\begin{array}{c}\text { Tuntas/ Tidak } \\
\text { Tuntas(KKM=60) }\end{array}$ \\
\hline 1. & Neli Hidayati & P & 20 & 55 & Tidak Tuntas \\
\hline 2. & Zikri Rahman & L & 20 & 80 & Tuntas \\
\hline 3. & Mardiatun Soleha & P & 20 & 65 & Tuntas \\
\hline 4. & Assani Hidayatullah & L & 20 & 75 & Tuntas \\
\hline 5. & Vira Dinda Lestari & P & 20 & 40 & Tidak Tuntas \\
\hline 6. & Muhibbudin abdul Aziz & L & 20 & 90 & Tuntas \\
\hline 7. & Maulidal Habibi & L & 20 & 80 & Tuntas \\
\hline & Maulida Ayu & P & 20 & 75 & Tuntas \\
\hline & & & & & \\
\hline
\end{tabular}


Vol. 10. No. 1. Tahun 2022

\begin{tabular}{|c|l|l|l|l|l|}
\hline 9. & M Ilhamdi & L & 20 & 55 & Tidak Tuntas \\
\hline 10. & M Aidil Akbar & L & 20 & 60 & Tuntas \\
\hline 11. & Nur Pia Wahyuni & P & 20 & 85 & Tuntas \\
\hline 12. & Nabila Putri & P & 20 & 80 & Tuntas \\
\hline 13. & Rindiani Safitri & P & 20 & 55 & Tidak Tuntas \\
\hline 14. & Wahidin Akbar & L & 20 & 75 & Tuntas \\
\hline $15 . \quad$ Yaumul Hadi & L & 20 & 80 & Tuntas \\
\hline 16. & Ziadatun Soleha & P & 20 & 100 & Tuntas \\
\hline 17. & Ilham Bayu Aditya & L & 20 & 85 & Tuntas \\
\hline 18. & Naura Fajria Nabiha & P & 20 & 90 & Tuntas \\
\hline Jumlah & & & 248 & \\
\hline Nilai Rata-rata & & & 69 & \\
\hline Jumlah Siswa Yang Tuntas & & & 14 & \\
\hline \multicolumn{2}{|l|}{ Persentase Ketuntasan Klasikal } & & & $78 \%$ & \\
\hline
\end{tabular}

Dari tabel di atas dapat dilihat bahwa ketuntasan belajar yang dicapai siswa adalah $\mathbf{7 8} \%$ dengan nilai rata-rata $69 \%$. Dari hasil observasi dan pengamatan yang dilakukan, didapatkan bahwa proses pembelajaran belum sesuai dengan yang diharapkan karena masih terdapat kekurangan-kekurangan baik dari pihak guru sendiri maupun dari pihak siswa, sehingga nilai klasikal belum mencapai standar klasikal yang ditentukan yaitu $80 \%$ mendapatkan nilai sama dengan standar KKM atau lebih dari standar KKM Hasil tes menunjukkan bahwa secara klasikal nilai rata-rata siswa baru sampai pada angka $78 \%$ dan nilai rata-rata baru mencapai $69 \%$.

Hasil tersebut belum mencapai hasil yang diharapkan, untuk itu peneliti melanjutkan ke siklus berikutnya. Dalam siklus I ini terdapat kekurangankekurangan yang perlu untuk dipehatikan dan diperbaiki pada kegiatan siklus II.

\section{Siklus II}

Pada tahap ini guru berorientasi pada pada hasil evaluasi belajar pada pelaksanaan siklus I. perencanaan pada siklus II dilakukan berdasarkan evaluasi dan reflekasi yang dilakukan pada siklus II dengn memperbaiki kekurangankekurangan pada siklus I. Meskipun dalam prosesnya guru melaksanakan kegiatan belajar-mengajar dengan program pengajaran yang sama dengan siklus I, namun dengan revisi atau perbaikan berdasarkan evaluasi dan reflekasi. Pada siklus II guru terlebih dahulu mengadakan revisi atau perbaikan terhadap kesalahan atau kekurangan yang dikalukan pada siklus I. Hal ini dilakukan pada kegiatan pendahuluan sebagai apersepsi pada siswa sebelum kegiatan belajarmengajar pada siklus II dilanjuktkan

Berdasarkan hasil observasi terhadap aktivitas siswa setelah dianalisa diperoleh data sebagai berikut :

\begin{tabular}{|l|l|l|l|l|l|l|l|l|l|}
\hline \multirow{2}{*}{ Pertemuan } & \multicolumn{6}{|c|}{$\begin{array}{c}\text { J Skor } \\
\text { aktivitas }\end{array}$} & $\begin{array}{l}\text { Rata-rata } \\
\text { Aktivitas }\end{array}$ & \multirow{2}{*}{ Kategori } \\
\cline { 2 - 10 } & 1 & 2 & 3 & 4 & 5 & 6 & \\
\hline Pertama & 4,6 & 3,0 & 4,0 & 3,3 & 3,6 & 4,6 & 23,1 & 3,85 & $\begin{array}{l}\text { Cukup } \\
\text { Aktif }\end{array}$ \\
\hline Kedua & 5,0 & 3,3 & 4,3 & 3,6 & 4,0 & 5,0 & 25,2 & 4,2 & Aktif \\
\hline
\end{tabular}

Dari tabel diatas dilihat bahwa aktivitas siswa pada siklus II untuk pertemuan 1 adalah 3,85 dan pertemuan 2 adalah 4,2. Kategori Aktif 
Data hasil belajar yang diperoleh dari siklus II adalah:

\begin{tabular}{|c|c|c|c|c|c|}
\hline No. & Nama Siswa & $\mathrm{L} / \mathrm{P}$ & Skor & Nilai & $\begin{array}{l}\text { Tuntas/ Tidak } \\
\text { Tuntas }\end{array}$ \\
\hline 1. & Neli Hidayati & $\mathrm{P}$ & 20 & 55 & Tidak tuntas \\
\hline 2. & Zikri Rahman & $\mathrm{L}$ & 20 & 60 & Tuntas \\
\hline 3. & Mardiatun Soleha & $\mathrm{P}$ & 20 & 85 & Tuntas \\
\hline 4. & Assani Hidayatullah & $\mathrm{L}$ & 20 & 75 & Tuntas \\
\hline 5. & Vira Dinda Lestari & $\mathrm{P}$ & 20 & 55 & Tidak tuntas \\
\hline 6. & Muhibbudin Abdul Azizz & $\mathrm{L}$ & 20 & 55 & Tidak tuntas \\
\hline 7. & Maulidal Habibi & $\mathrm{L}$ & 20 & 80 & Tuntas \\
\hline 8. & Maulida Ayu Soleha & $\mathrm{P}$ & 20 & 85 & Tuntas \\
\hline 9. & M Ilhamdi & $\mathrm{L}$ & 20 & 100 & Tuntas \\
\hline 10. & M Aidil Akbar & $\mathrm{L}$ & 20 & 85 & Tuntas \\
\hline 11. & Nur Pia Wahyuni & $\mathrm{P}$ & 20 & 90 & Tuntas \\
\hline 12. & Nabila Putri & $\mathrm{P}$ & 20 & 85 & Tuntas \\
\hline 13. & Rindiani Safitri & $\mathrm{P}$ & 20 & 100 & Tuntas \\
\hline 14. & Wahidin akbar & $\mathrm{L}$ & 20 & 90 & Tuntas \\
\hline 15. & Yaumul Hadi & $\mathrm{L}$ & 20 & 80 & Tuntas \\
\hline 16. & Ziadatu Soleha & $\mathrm{P}$ & 20 & 95 & Tuntas \\
\hline 17. & Ilham Bayu Aditya & $\mathrm{L}$ & 20 & 100 & Tuntas \\
\hline 18. & Naura Fajria Nabiha & $\mathrm{P}$ & 20 & 90 & Tuntas \\
\hline \multicolumn{2}{|c|}{ Jumlah } & & & 303 & \\
\hline \multicolumn{2}{|c|}{ Nilai Rata-rata } & & & 84 & \\
\hline \multicolumn{2}{|c|}{ Jumlah Siswa Yang Tuntas } & & & 15 & \\
\hline \multicolumn{2}{|c|}{ Persentase Ketuntasan Klasikal } & & & $83 \%$ & \\
\hline
\end{tabular}

Berdasarkan hasil perbaikan yang dilakukan dari 18 siswa ketuntasan klasikal mencapai $83 \%$, artinya bahwa siklus II penggunaan metode demonstrasi memiliki manfaat dan dapat meningkatkan nilai siswa baik secara individu ataupun rata-rata siswa secara keseluruhan..

\section{PEMBAHASAN}

Penelitian tindakan kelas ini dilaksanakan sebagai upaya untuk meningkatkan hasil belajar belajar IPA pada siswa kelas VI dengan melaksanakan pembelajaran dengan menerapkan/ menggunakan metode demonstrasi di SDN 2 Kelayu Jorong Tahun Pembelajaran 2020/2021.

Berdasarkan hasil analisis data pada tiap siklus, terlihat bahwa hasil dari siklus I ke siklus II mengalami peningkatan. Pada pelaksanaan pembelajaran dan hasil analisis data siklus I, untuk aktivitas siswa diperoleh kategori cukup aktif ) dan aktivitas siswa pada siklus II diperoleh aktivitas siswa dengan kategori (aktif)

Terkait dengan hasil ulangan pada siklus I dan II dapat dilihat rinciannya dibawah ini :

Tabel 4.5 : Ringkasan Hasil Evaluasi Pada Siklus I

\begin{tabular}{|l|l|c|}
\hline No & \multicolumn{1}{|c|}{ Uraian } & Hasil \\
\hline 1 & Nilai Terendah & 45 \\
\hline 2 & Nilai Tertinggi & 100 \\
\hline 3 & Rata-rata & 69 \\
\hline 4 & Jumlah siswa yang tuntas & 12 \\
\hline 5 & Jumlah siswa yang ikut tes & 18 \\
\hline 6 & Persentase yang tuntas & $66 \%$ \\
\hline
\end{tabular}


Sedangkan pada siklus II hasilnya sebagai berikut :

Tabel 4.6 : Ringkasan Hasil Evaluasi Pada Siklus II

\begin{tabular}{|l|l|c|}
\hline No & \multicolumn{1}{|c|}{ Uraian } & Hasil \\
\hline 1 & Skor Terendah & 55 \\
\hline 2 & Skor Tertinggi & 100 \\
\hline 3 & Rata-rata & 84 \\
\hline 4 & Jumlah siswa yang tuntas & 15 \\
\hline 5 & Jumlah siswa yang ikut tes & 18 \\
\hline 6 & Persentase yang tuntas & $83 \%$ \\
\hline
\end{tabular}

Setelah melihat kedua tabel hasil evaluasi dari siklus I dan II dimana nilai yang mereka peroleh sudah mencapai tingkat ketuntasan belajar. Dan melebihi tingkat ketuntasan belajar secara klasikal yaitu $80 \%$.Penelitian tindakan kelas ini dilaksanaan sebagai upaya untuk meningkatkan aktivitas dan hasil belajar IPA pada materi kemagnetan melalui penerapan metode demonstrasi. dimana penelitian ini dilakukan dalam dua siklus.

\section{KESIMPULAN}

Dalam pembelajaran IPA yang penuh dengan pembelajaran praktek langsung guru harus melihat mana metode yang lebih efektif digunakan di setiap pertemuan agar siswa dapat dengan mudah memahami pelajaran tersebut. Karena disamping mendengarkan penjelasan guru siswa juga mendapatkan kesempatan belajar dengan cara terjun langsung melakukan suatu peragaan sampai selesai. Tujuannya adalah agar siswa tetap ingat pada pelajaran yang pernah diberikan gurnya sampai kapanpun.

Hal ini akan memancing aktivitas siswa dimana siswa akan terlibat dalam proses pembelajaran. Disamping itu juga memberikan pengalaman belajar melalaui perbuatan, melihat dan mendengarkan diikuti dengan meniru pekerjaan yang didemonstrasikan, sehingga dengan sendirinya siswa akan langsung mengalami pelajaran yang diberikan oleh gurunya.

Berdasarkan hasil penelitian dan pembahasan diatas, dapat di simpulkan bahwa Penerapan metode demonstrasi dapat meningkatkan aktivitas dan hasil belajar siswa di SDN 2 Kleayu Jorong kelas VI tahun 2021. Peningkatan tersebut dapat dilihat dari perolehan nilai skor aktivitas siswa, dan nilai rata-rata kelas serta tingkat ketuntasan secara klasikal pada tiap siklus mengalami peningkatan baik pada siklus I maupun siklus II.

Dari hasil penelitian dan pembahasan di atas dapatlah kami simpulkan Penerapan metode demonstrasi dapat meningkatkan hasil belajar mata pelajaran IPA pada siswa kelas VI SDN 2 Kelayu Jorong Tahun Pelajaran 2020/2021

\section{DAFTAR PUSTAKA}

Abu, Ahmadi dan Cholid, Narbuko. 2005. Metodologi Penelitian. Bumi Aksara: Jakarta.

Arikunto Suharsimi. 2000. Prosedur Penelitian Suatu Pendekatan Praktis. Renika Cipta Jakarta.

Departemen Pendidikan dan Kebudayaan RI. 2002. Petunjuk Pelaksanaan Proses Belajar Mengajar di Sekolah Dasar. Jakarta. Dijen Dikdasmen.

Fajar Arni. M. pd. 2004 Portofolio dalam Pelajaran IPS, PT. Remaja Rosdakarya : Bandung

Faisal Sanapiah. 2002. Dasar-dasar Penelitian. Surabaya. Indonesia.

Nasution. S. 2004, Metode Research (penelitia ilmiah).PT Bumi Aksara: Jakarta

Nurkencana, W. Sumartana, PPN.2002. Evaluasi Pendidikan. Surabaya. Usaha Nasional.

Poerdarminto, W. J. S. 2003. Belajar dan Faktor yang Memperngaruhinya. Rieneka Cipta. Jakarta. 
Journal Ilmiah Rinjani (JIR)

ISSN-p: 2442-3416

Media Informasi Ilmiah Universitas Gunung Rinjani

Vol. 10. No. 1. Tahun 2022

Purwanto, Ngalim. 2004 Prinsip-prinsip dan

Tehnik Evaluasi pengajaran.PT

Remaja Rosda Karya. Bandung.

Ruseffendi. 2001. SetrategiBelajar Mengajar. Rieneka Cipta. Jakarta.
ISSN-e: 2714-6049

Wina Sanjaya. 2001. Mengajar dan Belajar dalam Standar Proses Pendidikan. PT. Bumi Aksara. Jakarta. 